\title{
An Evaluation of Factors Considered while Selecting Mutual Funds: A Case of Brokers in Punjab
}

\author{
Anu Sahi ${ }^{1}$, Dr. Anurag Pahuja ${ }^{2}$, Dr. Balram Dogra ${ }^{3}$ \\ ${ }^{1}$ Research Scholar, Punjab Tehnical University, Jalandhar \\ ${ }^{2}$ Assistant Professor, Apeejay Institute of Management, Technical Campus, Jalandhar \\ ${ }^{3}$ Vice Chancellor, Sri Sai Unviersity, Palampur
}

\begin{abstract}
The past years have been a defining period for the mutual fund industry, as lack of incentivisation has made it increasingly burdensome for the distributor to reach out to the retail investor. Rather, role of distribution channel is phenomenal in delivery of product or service. Majority of the investors relies on financial advisors for choosing mutual funds. Hence, it is imperative to unveil the factors considered while selecting mutual funds and attributes affecting success of mutual funds. It is a maiden effort in this regard, since no such empirical study as per best of our knowledge has been conducted in the state of Punjab till date.
\end{abstract}

Keywords: Incentivisation; Financial advisors

\section{Council for Innovative Research}

Peer Review Research Publishing System

Journal: International Journal of Management \& Information Technology

Vol. 9, No. 3

editor@cirworld.com

www.cirworld.com, member.cirworld.com 


\section{INTRODUCTION}

Indian Mutual fund Industry has been grown spectacularly since inception with a more intricate structure and rising diversification. Distribution channel plays a fundamental role in delivery of product or service.

Moreover, recognizing such characteristics might steer small investors in their investment decisions. This paper aims to appraise the attributes that independent financial advisors consider while selecting the funds and to establish the relative significance of these attributes to make mutual funds a part of portfolio basket of retail investors

A Mutual Fund could be defined as a trust that pools the savings of a number of investors who share a common financial goal. The money thus collected is then invested in capital market instruments such as shares, debentures and other securities.

The income earned through these investments and the capital appreciation realized is shared by its unit holders in proportion to the number of units owned by them.

Thus a Mutual Fund is the most suitable investment for the common man as it offers an opportunity to invest in a diversified, professionally managed basket of securities at a relatively low cost. The Securities and Exchange Board of India (Mutual funds) Regulations, 1996 defines a mutual fund as a fund established in the form of a trust to raise money through the sale of units to the public or a section of the public under one or more schemes for investing in the securities including money market instruments.

Table 1. Snapshot of Indian Mutual fund Industry

\begin{tabular}{|l|l|l|l|l|}
\hline Phase & Period & Players & $\begin{array}{l}\text { No. } \\
\text { AMCs* }\end{array}$ & AUM (Rs. $^{\star *}$ \\
\hline First & $1964-1987$ & UTI & Only UTI & $6700 \mathrm{Cr}$. \\
\hline Second & $1987-1993$ & Entry of Public Sector & 9 & $47004 \mathrm{Cr}$ \\
\hline Third & $1993-2003$ & Entry of Pvt. Sector \& Foreign Players & 31 & $121805 \mathrm{Cr}$. \\
\hline Fourth & $\begin{array}{l}\text { Since 2003 till 31 March } \\
2013 \\
\text { (Consolidation \& Growth) }\end{array}$ & $\begin{array}{l}\text { Pvt. Public, Foreign and Bank sponsored } \\
\text { players }\end{array}$ & 46 & $\begin{array}{l}7 \text { lakh crore } \\
\text { appx. }\end{array}$ \\
\hline
\end{tabular}

(Source: www.amfiinida.com) *AMC stands for Asset Management Company*^AUM stands for Asset under Management.

Despite the impressive figures as shown in table 1. The state of Mutual funds in India is deplorable as compared to many developed and developing countries. The AUM to GDP ratio, which explains the amount contributed towards GDP by the Asset under Management is meager

in India. Fig 1, shows that contribution of AUM to GDP is highest that of $77 \%$ while share of India is just $5 \%$.These statistics throw light on some of the story of Indian Mutual fund Industry.

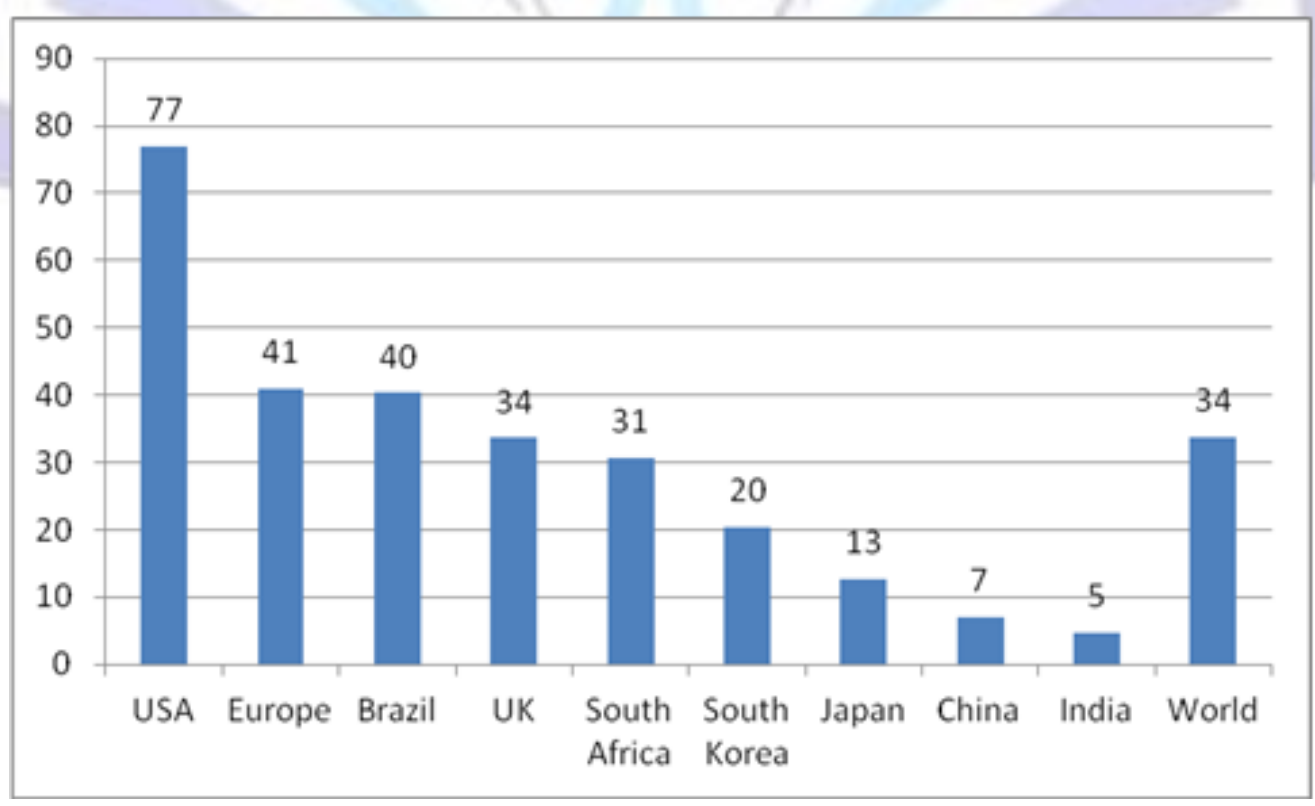

Fig1. AUM to GDP Ratio 


\section{REVIEW OF LITERATURE AND RESEARCH METHODOLOGY}

Factors considered by investment advisors and fund managers in selecting mutual funds have been highlighted in Gozbasi and Citak (2010) using conjoint analysis. Similarly, Lakshmi 2007 has identified the perception of brokers towards mutual funds and uncover role of brokers as well as factors considered by brokers while suggesting mutual funds to their clients.

Saini et al.2011 also tried to focus on role of brokers in mutual fund industry and evaluated investor perception towards brokers. Unfortunate to quote that the study highlighted that though investors rely heavily on their investment advisor, yet got cheated by them many times.

The brokers found to be involved generally in meeting their personal goals rather then ethical advising. Mehta 2011 made an attempt to underline the broker's opinion towards mutual funds and found brokers to be confused.

In order to reach at meaningful conclusion, present paper has used descriptive statistics, measures of central tendencies and gamma correlations for the same.

\section{Research Findings}

Table 2.Descriptive Statistics of Surveyed Brokers

\begin{tabular}{|c|c|c|c|c|c|}
\hline \multicolumn{3}{|c|}{ Profile of Brokers } & Frequency & Percent & Chi Square \\
\hline \multirow{3}{*}{\multicolumn{2}{|c|}{ Education* (48) }} & +2 Schooling & 02 & 4.2 & \multirow{3}{*}{$\begin{array}{c}x^{2}=33.5, d f=2, p< \\
0.05\end{array}$} \\
\hline & & Graduation & 34 & 70.8 & \\
\hline & & Post Graduation & 12 & 25.0 & \\
\hline \multirow{3}{*}{$\begin{array}{l}\text { Age of } \\
(48)\end{array}$} & \multirow[t]{3}{*}{ Business* } & $>5$ years & 01 & 2.1 & \multirow{3}{*}{$\begin{array}{c}x^{2}=68.6, d f=2, p< \\
0.05\end{array}$} \\
\hline & & $5-15$ years & 04 & 8.3 & \\
\hline & & > 15years & 43 & 89.6 & \\
\hline \multirow{2}{*}{$\begin{array}{l}\text { Area of } \\
(50)\end{array}$} & \multirow{2}{*}{ Operations } & Semi Urban & 08 & 16.0 & \multirow{2}{*}{$\begin{array}{c}x^{2}=23.1, d f=1, p< \\
0.05\end{array}$} \\
\hline & & Urban & 42 & 84.0 & \\
\hline \multirow{6}{*}{$\begin{array}{l}\text { Annual } \\
(45)\end{array}$} & \multirow[t]{6}{*}{ Turnover** } & $<5$ lac & 12 & 26.7 & \multirow{6}{*}{$\begin{array}{c}x^{2}=17.2, d f=5, p< \\
0.05\end{array}$} \\
\hline & & $5-25$ lac & 10 & 22.2 & \\
\hline & & $25-50 \mathrm{lac}$ & 02 & 4.4 & \\
\hline & & $50-1 \mathrm{cr}$ & 01 & 2.2 & \\
\hline & & $1-3 \mathrm{cr}$ & 07 & 15.6 & \\
\hline & & $>3 \mathrm{cr}$ & 13 & 28.9 & \\
\hline
\end{tabular}

\section{FUND CHARACTERISTICS CONSIDERED WHILE SELECTING MUTUAL FUNDS}

Majority of the investors prefers to take broker advice while making any investment decision. So it is imperative to know what fund characteristics are considered by brokers while suggesting investment in mutual funds.

The respondent brokers were asked to rate the various fund characteristic on the basis of importance on a 5 point likert scale $((1=$ Strongly Disagree, $2=$ Disagree, $3=$ Neutral, $4=$ Agree, $5=$ Strongly Agree $)$. The results are as follows:

Table 3: Fund Characteristics Considered While Selecting Mutual Fund Scheme

\begin{tabular}{|c|c|c|c|c|c|c|}
\hline Fund Characteristics & Minimum & Maximum & Mean & Std. Deviation & Summated Score & Rank \\
\hline Relative fund performance & 3.00 & 5.00 & 4.4167 & .57735 & 212.00 & 1 \\
\hline Fund Objective & 2.00 & 5.00 & 4.1875 & .64102 & 201.00 & 4 \\
\hline Fund Risk & 1.00 & 5.00 & 3.9167 & 1.10768 & 188.00 & 8 \\
\hline
\end{tabular}




\begin{tabular}{|c|c|c|c|c|c|c|}
\hline Fund Management team & 2.00 & 5.00 & 4.3542 & .75764 & 209.00 & 2 \\
\hline Absolute fund performance & 1.00 & 5.00 & 4.3125 & .99266 & 207.00 & 3 \\
\hline Fund Age & 2.00 & 5.00 & 4.0417 & .84949 & 194.00 & 6 \\
\hline Fund Expense & 2.00 & 5.00 & 4.1250 & .84110 & 198.00 & 5 \\
\hline Tax efficiency & 1.00 & 5.00 & 3.7708 & .97281 & 181.00 & 9 \\
\hline Fund Size & 3.00 & 5.00 & 3.9792 & .75764 & 191.00 & 7 \\
\hline Fund Rating & 1.00 & 5.00 & 3.8043 & 1.12782 & 175.00 & 10 \\
\hline
\end{tabular}

Note: Mean is an average on five point liker scale where (1=Strongly Disagree, $2=$ Disagree, 3 = neutral, $4=$ Strongly Agree, 5= Strongly Agree) $\mathrm{N}=50$

In conformance to the results of (Jones et al.2005; Gozbasi and Citak, 2010), table 3 unveiled that on the basis of mean scores "Relative performance of a fund with similar other funds" (Mean Score 4.41) is the most important feature followed by "Fund management team" (Mean Score 4.35) and "Absolute fund performance (mean score 4.31) feature considered while selecting the funds by the brokers.

\section{ATTRIBUTES AFFECTING SUCCESS OF MUTUAL FUNDS}

There can be number of attributes which can be considered while selecting the mutual funds as choice of attribute affect the success of mutual funds. However, there are certain vital factors while some are desirable. In order to know the perception of brokers regarding the most influential factor which is responsible for making mutual fund success this question was framed on a five point scale where ( $1=$ Strongly Disagree, $2=$ Disagree, $3=$ Neutral, $4=$ Agree, $5=$ Strongly Agree) and the response is as under:

Table 4: Attributes affecting success of Mutual Funds

\begin{tabular}{|c|c|c|c|c|c|}
\hline Sr. No. & Attributes & N & Mean & Std. Deviation & Rank \\
\hline F1 & Quality of Service & 50 & 4.5102 & .79379 & 2 \\
\hline F3 & $\begin{array}{c}\text { Suitability of } \\
\text { Product }\end{array}$ & 50 & 4.4200 & .92780 & 3 \\
\hline F4 & $\begin{array}{c}\text { Risk Orientation } \\
\text { Number of } \\
\text { Service Centers }\end{array}$ & 50 & 4.2200 & .81541 & 6 \\
\hline F5 & $\begin{array}{c}\text { Experienced } \\
\text { Fund } \\
\text { Management } \\
\text { Team }\end{array}$ & 50 & 4.6875 & .51183 & 1.07457 \\
\hline F6 & $\begin{array}{c}\text { Brand Value of } \\
\text { AMC }\end{array}$ & 50 & 3.9600 & 1.02936 & 5 \\
\hline
\end{tabular}

Table 4 clearly reveals that "Experienced fund management" team has the highest mean (4.68) followed by "Quality of service" (4.51) and "Suitability of product" (4.42) as the most important attribute responsible for success of mutual fund. Analogous to this was findings of (Lakshmi, 2012; Mehta, 2011; Goel, 2012)

Hence it can be said that the respondent brokers consider that in order to make a mutual fund success the most important factor is experienced fund management team and quality of service and the least important factors are "Brand value of AMC" (3.96) and "Number of service centers" (3.7800) (Gozbasi and Citak, 2010). 
Table 5: Gamma Correlations between Various Attributes Considered For Success of Mutual Funds

\begin{tabular}{|c|c|c|c|c|c|c|}
\hline Attributes & Quality & Suitability & Risk & Number & Experience & Brand \\
\hline $\begin{array}{c}\text { Quality of } \\
\text { Service }\end{array}$ & -- & 0.148 & -0.316 & 0.102 & -0.419 & $0.412^{* *}$ \\
\hline $\begin{array}{c}\text { Suitability of } \\
\text { Product }\end{array}$ & -- & -- & 0.294 & $0.539^{* *}$ & $0.830^{* *}$ & -0.291 \\
\hline Risk Orientation & -- & -- & -- & -0.184 & $0.500^{* *}$ & -0.148 \\
\hline $\begin{array}{c}\text { Number of } \\
\text { Service Centers }\end{array}$ & -- & -- & -- & $--816^{* *}$ & 0.329 \\
\hline $\begin{array}{c}\text { Experienced } \\
\text { fund } \\
\text { Management } \\
\text { Team }\end{array}$ & -- & -- & -- & -- & 0.006 \\
\hline
\end{tabular}

The gamma correlations between attributes made it clear that suitability of product and experienced fund management team are highly correlated and hence can be said that these are two major attributes affecting success of mutual funds.

\section{CONCLUSION}

To conclude with, it can be said that brokers play a prominent role in making mutual fund reach to investors. The study unveiled that relative fund performance, fund management team and absolute fund performance are the three main factors considered by brokers while selecting the mutual funds. While on the basis of their experience they have found that experience of fund manager and the entire fund management team is considered to be the most important attribute affecting success of mutual funds. Further the study also disclosed that fund suitable according to the needs of investors and experienced fund management team are two highly correlated attributes making mutual fund successful.

\section{REFERENCES}

[1] Mehta, P.U., (2011), "Profile and Perception of Investors towards Mutual Funds: A Study of Selected Cities of Gujarat City", Ph.D Thesis, Veer Narmada South Gujarat University, Surat.

[2] Gozbasi, O., and Citak, L.,(2010), "An Evaluation of the Attributes Considered by Investment Professionals in Selecting Mutual Funds: The Case of Turkey", International Research Journal of Finance and Economics, 36(2010), pp.180-195.

[3] Saini, S., Anjum,B., and Saini, R.,(2011), "Investors Awareness and Perception Towards Mutual Funds", Zenith International Journal of Multidisciplinary Research, 1(1), pp.14-29.

[4] Pathak, Bharati. V., (2008), The Indian Financial System. Markets, Institutions and Services, Pearson Education, New Delhi, pp. 608-645.

[5] Gordon, E. and Natarajan, K., (2010), Financial Markets and Services, Himalaya Publishing House Pvt. Ltd. New Delhi, pp.330-365

[6] Banerjee, J., and Roy, S., (2012), "Customer Perception on Mutual fund Product: A Technical Analysis", Interscience Management Review, 2(2), pp.63-66.

[7] Bergstresser, D., Chalmer, J., and Tufano, P., (2009), "Assessing the Cost and Benefit of Brokers in Mutual Fund Industry", Review of Financial Studies, 22(10), pp. 4129-4156.

[8] Lakshmi, N., (2012), "Performance of Indian Mutual Fund Industry: A Study with Special Reference to Growth Schemes", Ph.D Thesis, Pondicherry University, Pondicherry

[9] Singh, J., (2003), "Growth, Performance and Prospects of Mutual Funds in India”, Ph.D Thesis, Guru Nanak Dev University, Amritsar.

[10] Jones, M.A., Lesseig, V.P., and Symthe, T.I., (2005), "Financial Advisors and Mutual Fund Selection", Journal of Financial Planning, March 2005, pp.64-70

[11] Sweta, G., (2013), "Performance of Mutual Funds and Investor Behavior", Ph.D Thesis, Jaypee Institute of Information Technology, Noida. 


\section{ISSN 2278-5612}

[12] Goel, S., Goel,S., Sharma, R. and Mani, M.,(2012), "A study of performance and characteristics of open ended mutual; funds", Asian journal of Management research, 3(1), pp.116-124.

[13] SEBI- NCEAR Survey (2011), "How Households Save and Invest: Evidence from NCAER household survey", SEBI, Mumbai 